\title{
Public Goods and Public Spirit
}

\author{
Des Gasper and Flavio Comim
}

Pre-final version of chapter in: Agency, Democracy and Participation in Global Development, eds. L. Keleher, S. Kosko; Cambridge University Press, 2017

\section{Introduction: liberté, égalité - et fraternité?}

This paper connects two fundamental topics in political philosophy and development ethics: the role of feelings in public life, and the nature and provision of public goods. It links philosophical discussions of publicness and compassion in policy with the more policy-practical topics of public goods. 'Publicness' is used here as an umbrella term for the moral sentiments that sustain the structures of cooperation and solidarity seen in a society. The term helps us to consider the connections between public goods, public information, public reason and people's values and cultures.

We will put forward a conceptualization of priority (or 'basic') public goods, and of public values required to induce support for provision of those goods. This leads to, centrally, an appraisal of Martha Nussbaum's notable recent study of political emotions. We will refer to other research on value commitments, and to the global as well as the national scale, including from discussions of human security and human rights.

The provision of public goods is at the heart of much of human development. The extent of such provisions is an indication of a society's normative priorities, yet not much attention is usually given in economic development theory and even human development theory to how these priorities are established as an expression of the quality of public commitment or public spirit in a society. While the importance of individualism for economic growth and human development has been widely argued, and the relevance of 'social capital' has become fashionable in social sciences since the 1990s, what of publicness? How can we understand its importance to human development? Is 'public spirit' part of 'social capital'? Contemporary deliberative ethics talks much more about public reason and dialogue than about public sentiments and commitment (see e.g. Crocker 2008, Sen 2009). ${ }^{i}$

Development theorists of the 1940 s to 1970 s do not seem to have given much attention to the theme of publicness, except in some discussions of nation-building and corruption in relation to perceptions of what are public and private spheres (see e.g. Goulet 1971, Gasper 2006a). Some hints appear in 1970s and 80s discussions of human needs, and in participatory theories of development since the 1990s. The human development work inspired by Amartya Sen has also led in this direction, including in Sen's books with Jean Drèze; but much capability approach work has been limited by weak elaboration of social and psychological dimensions. According 
to the anthropologist Mary Douglas it reflected a social sciences weakness of 'Missing [real] Persons' (Douglas and Ney 1998). Sen's category of 'commitment', meaning holding of objectives oriented to the good of others, remains a relatively empty box in his system, not presented as foundational in the same way as the categories of freedom and equality. His work has ventured relatively little into the substantive contents and social determinants of commitment, compassion, fraternity and solidarity.ii

A new survey of the BRICS countries (Anand et al., forthcoming) examines many dimensions of their economic rise and their degrees of accompanying political, social and cultural evolution. Has growing economic wealth been matched by growth of values and institutions that build and secure an equitable and decent society? Comim (2015) distinguishes, first, a 'Senian level', concerning persons' degree of effective access to basic or priority functionings; this partly rests on, second, a 'Rawlsian level', concerning state support for the provision, whether by state or other actors, of primary or basic goods; and both partly depend on, third, a 'Nussbaumian level', concerning the public culture of mutual respect and concern needed to sustain basic goods, effective access and a society that promotes a life with dignity for all. Comim operationalizes these levels through reference to relevant indicators; and presents a composite index spanning the three, which is applied to the five BRICS.iii The results are striking: an enormous gulf between the measures for overall publicness (reflecting public provisions, attainments, and indications of mutual concern) in Brazil, China and Russia versus South Africa and, especially, India.iv While the indicators for each of the levels are subject to debate, likewise the data used and the principles of aggregation, the gulf is so extreme that fundamental questions arise, including about the bases of identification in pluralist societies.

Whereas pluralism has been widely praised by leading human development theorists (Nussbaum, 2006; Sen, 2009), much remains to be said about the collective and cultural processes that shape publicness in different societies and about its roles in human development. Not least, the links between market processes and barriers to deeper communication between individuals have so far been largely ignored, warned Evans (2002).

We will look later in this paper at India, perhaps the main target in Sen's discussions of public reason and (together with the USA) in Nussbaum's discussions of political or public emotions. India already has a much higher average per capita income than did many other countries (such as China, Korea, Sri Lanka, Taiwan, Thailand) when they initiated effective programmes for universal access to various basic public goods. CES (2014) documents India's continuing failures in provision of basic public goods at the 'Rawlsian level', and generates questions about Indian political culture(s) and the weakness of values of public compassion-in-action. Mander's book Looking Away (2015) explores these values, arguing that increasing marginalization of vulnerable people has been accompanied by growing ideologies of possessive exclusivism that justify the marginalization. 
The focus of the paper is however not a country case, but how authors conceptualize (or ignore) the dimensions and challenges of publicness, mutually concerned cooperative interaction. Could we explain publicness just as a product of individual choices, subject to strategic voting, manipulation, collective agency problems and so on? Much work of this nature considers people's moral sentiments as an outcome of individual preference orderings (Pattanaik, 2014), ignoring agents' socialization and the origins of their motives and emotions. Nussbaum's Political Emotions offers a deeper treatment; it employs a complex theory of emotions and draws from a range of historical experiences. It remains mainly at the level of philosophical and literary value discourse, with limited attention to the political challenges of building coalitions and even new identities around and for public priority goods, as in arenas like sanitation (cf. Wuyts 1992), let alone across national boundaries; but includes helpful case studies including from city planning, the American New Deal, and Gandhi's strategy as a social reformer. By not merely pointing to the need for a social psychology of emotions but starting to offer one, Nussbaum's work generates many essential further questions.

In our discussion of this core area for development ethics and human development we attempt, in the spirit of David Crocker's work, to bring together diverse sources in philosophy, social sciences and policy analysis, and to introduce global and not only domestic perspectives. The paper cannot itself go far on many of the issues it raises; but it raises an agenda for future work.

\section{Preliminaries: public priority goods and public commitment ${ }^{v}$}

Richard Sennett notes that "The first recorded uses of the word 'public' in English identify the 'public' with the common good in society" (1977: 16). His The Fall of Public Man (1977) analyses the evolution of public life in 18th-19th century European capitals, especially Paris and London. During the growth of these cities many public spaces were lost, to the special detriment of poorer people, as part of growing privatization of both physical and mental space. A countermovement slowly emerged to try to establish worthwhile public spaces open to all. Nussbaum's book gives much attention to the successful realization of public parks in some cities and their disastrous absence in others. The nature and extent of public spaces in cities provides powerful visible evidence about how far people consider themselves as part of the same society. Inclusive cities have important public areas and promote an experience of living together; exclusive cities separate people, promote individuality and further the isolation of individuals. Spatial inequalities reinforce economic ones and deepen social distance, which in turn weakens social cooperation and feelings of publicness among individuals, eroding what Sennett (2012) called the cooperative frame of mind'.

John Gray notes that public spaces are examples of what Joseph Raz (1986) called 'inherently public goods', which 
do not necessarily satisfy the technical requirements of an economic public good ... [but] are ingredients in a worthwhile form of common life. Consider public parks in the context of a modern city... There are, of course, no insuperable technical obstacles to turning urban parks into private consumption goods... [But] Public spaces for recreation and for lingering, whether streets, squares or parks, are necessary ingredients in the common life of cities, as conceived in the European tradition and elsewhere. Where such public places atrophy or disappear, become too dangerous or too unsightly to be occupied... the common life of the city has been compromised or lost. (Gray, 1993: 134).

Other work in social philosophy, such as by Abram de Swaan (1988), similarly rejects the conception in which a 'public good' is merely a good which does not well fit into the operation of private markets; and presents instead a notion of public priority good (see Wuyts 1992). In the same spirit, the India Exclusion Report (CES 2014) defines a 'basic public good' as a requisite for a life with dignity.

"Public is a pre-governmental concept which broadly describes the full range of human collective activities which are outside of our private homes and distinct from the market of the private pursuit of gain" (Frederickson, 1996: 299). The concept comes from the Latin publicus, derived in turn from pubes meaning adult. It has now a complex of meanings including these three as an adjective (Oxford English Reference Dictionary, 1996): (1) of or concerning the people as a whole, (2) of or involved in the affairs of the community, and (3) provided by or concerning local or central government-but provided not for government itself, instead for the whole public. Concomitantly, 'public goods' are not only provided by the State. Thus, the concept of 'public' means that which is and/or appropriately should be managed or held in common and for the common good. People declare that issue $\mathrm{X}$ is a matter of public concern, meaning it should be subject to community attention and steering even if it presently is not; and conversely that issue $Y$ is not, meaning it should not be a matter for community regulation even if it presently is. Different views about the grounds for 'should' and about the 'common good' lead to different views about which things are public goods and what is the appropriate extent of public action. Whatever the specific view, the provision of public goods depends on a commitment to these goods as priorities for the common good.

Mainstream economics has historically focused on the market. 'Private goods', those that are rivalrous and excludable, fit its predictive and prescriptive claims about markets better. ${ }^{\text {vi }}$ In neo-classical economics public goods are the problem cases that fit poorly in markets: goods which are non-rivalrous and/or non-excludable. The pure public good (or bad) is both those, so 'free-riding' is possible, and funding and hence provision of the good are inhibited. Such goods are not public in the sense of being automatically publicly available. What makes such a good publicly available, and hence a public good in an everyday sense, is (a) a decision that it is important enough and then (b) some form of public action. vii What is chosen for actual public provision covers far less than all non-excludables, and includes some excludables. Education and health care are both rivalrous and excludable services; yet both may 
be supported or provided by public agents to be accessible to ordinary people, often through a subsidy, because they are seen as 'merit goods', deserving priority, and because their 'consumption' brings important favourable external effects for others.

TABLE 1: CONCEPTS OF HUMAN SECURITY, HUMAN NEED, AND HUMAN RIGHTS

(Adapted from Gasper 2005)

\begin{tabular}{|c|c|c|c|c|c|}
\hline & $\begin{array}{c}\text { Basic } \\
\text { Criterion for } \\
\text { Priority/Need }\end{array}$ & $\begin{array}{l}\text { Needs level 1: } \\
\text { Requirements } \\
\text { in order to } \\
\text { fulfil the basic } \\
\text { criterion }\end{array}$ & $\begin{array}{l}\text { Needs level 2: } \\
\text { Satisfier } \\
\text { characteristics } \\
\text { required to } \\
\text { achieve level } 1\end{array}$ & $\begin{array}{l}\text { Needs level 3: } \\
\text { Specific } \\
\text { required } \\
\text { satisfiers to } \\
\text { achieve level } 2\end{array}$ & $\begin{array}{l}\text { Needs level 4: } \\
\text { Required } \\
\text { preconditions } \\
\text { for level } 3\end{array}$ \\
\hline $\begin{array}{c}\text { Human Security } \\
\text { / Human } \\
\text { Development: } \\
\text { prioritization using } \\
\text { the categories of the } \\
\text { capability approach } \\
\text { and UNDP's 'Human } \\
\text { Development' }\end{array}$ & $\begin{array}{l}\text { Priority } \\
\text { functionings: } \\
\text { 'vital core' of } \\
\text { human lives } \\
\text { (CHS 2003) }\end{array}$ & $\begin{array}{l}\text { Capabilities that } \\
\text { are required to } \\
\text { achieve the } \\
\text { priority } \\
\text { functionings: } \\
\text { 'basic } \\
\text { capabilities' }\end{array}$ & $\begin{array}{l}\text { 'Characteristics' } \\
\text { of goods that are } \\
\text { required to } \\
\text { achieve those } \\
\text { capabilities }\end{array}$ & $\begin{array}{l}\text { The goods / } \\
\text { 'commodities' } \\
\text { that are required } \\
\text { to provide those } \\
\text { characteristics }\end{array}$ & $\begin{array}{l}\text { The societal } \\
\text { conditions that } \\
\text { are required to } \\
\text { sustain the } \\
\text { supply of those } \\
\text { goods }\end{array}$ \\
\hline $\begin{array}{c}\text { Theory of Human } \\
\text { Need } \\
\text { Doyal \& Gough's } \\
\text { main formulation of } \\
\text { human needs as } \\
\text { normative priorities }\end{array}$ & $\begin{array}{l}\text { Avoidance of } \\
\text { serious harm; } \\
\text { and ability to } \\
\text { function as an } \\
\text { effective full } \\
\text { member of } \\
\text { society }\end{array}$ & $\begin{array}{l}\text { Health, physical } \\
\text { and mental; } \\
\text { autonomy of } \\
\text { agency }\end{array}$ & $\begin{array}{c}\text { Nourishment; } \\
\text { housing; } \\
\text { secure } \\
\text {-childhood \& } \\
\text {-environment; } \\
\text { work; health } \\
\text { care, education, } \\
\text { \&c. }\end{array}$ & $\begin{array}{l}\text { The satisfiers } \\
\text { required, which } \\
\text { vary according to } \\
\text { geographical, } \\
\text { socio-economic } \\
\text { and cultural } \\
\text { setting }\end{array}$ & $\begin{array}{l}\text { Conditions } \\
\text { concerning } \\
\text { production, } \\
\text { reproduction, } \\
\text { cultural } \\
\text { transmission, } \\
\text { and political } \\
\text { authority } \\
\end{array}$ \\
\hline $\begin{array}{c}\text { Human Rights: } \\
\text { Goldewijk \& } \\
\text { Fortman's } \\
\text { formulation }\end{array}$ & $\begin{array}{l}\text { Dignity / non- } \\
\text { humiliation } \\
\text { Self-respect }\end{array}$ & $\begin{array}{l}\text { Equality and } \\
\text { freedom; or, } \\
\text { equality and } \\
\text { agency }\end{array}$ & $\begin{array}{l}\text { The satisfier } \\
\text { characteristics } \\
\text { required for } \\
\text { equality and } \\
\text { freedom/agency }\end{array}$ & $\begin{array}{l}\text { Specific satisfiers } \\
\text { that provide the } \\
\text { required } \\
\text { characteristics; } \\
\text { vary by setting }\end{array}$ & $\begin{array}{c}\text { A culture of } \\
\text { commitment to } \\
\text { the dignity of all } \\
\text { persons }\end{array}$ \\
\hline $\begin{array}{l}\text { Education example } \\
\text { The more ambitious } \\
\text { the generative/basic } \\
\text { value-criterion (e.g. } \\
\text { critical autonomy } \\
\text { too), the more } \\
\text { ambitious will be the } \\
\text { type of required } \\
\text { education, \& the } \\
\text { greater the } \\
\text { supportive requisites }\end{array}$ & $\begin{array}{l}\text { E.g.:- } \\
\text { A life of human } \\
\text { dignity and } \\
\text { compassion }\end{array}$ & $\begin{array}{l}1 \text { - Literacy, } \\
\text { numeracy, etc. = } \\
\text { Learning to know } \\
2 \text { - Operacy; } \\
\text { autonomy of } \\
\text { agency = } \\
\text { Learning to do } \\
3 \text { - Learning to be } \\
4 \text { - Learning to } \\
\text { live together. } \\
\text { (The four } \\
\text { UNESCO 'Pillars } \\
\text { of Learning') }\end{array}$ & $\begin{array}{c}\text { Competent } \\
\text { schooling } \\
\text { Good parenting } \\
\text { \&c. }\end{array}$ & $\begin{array}{l}\text { Accessible school } \\
\text { facilities } \\
\text { Competent } \\
\text { motivated } \\
\text { humane teachers } \\
\text { \&c. } \\
\text { Family incomes } \\
\text { that free children } \\
\text { from long } \\
\text { working hours }\end{array}$ & $\begin{array}{l}\text { Economic } \\
\text { capacity } \\
\text { Nussbaumian } \\
\text { public spirit; } \\
\text { sufficient social } \\
\text { solidarity to } \\
\text { sustain these } \\
\text { required } \\
\text { satisfiers }\end{array}$ \\
\hline
\end{tabular}

The public priority goods notion itself remains insufficient, for each majority government could declare that it prioritizes in its own way, a way that (perhaps tacitly) excludes some groups. The notion thus requires fuller theorization, including connection to needs theory, plus institutional entrenchment of basic requirements for all, as via a human rights formulation. Table 1 shows how a ladder of implied needs, of increasing specificity as we descend (from left to right in the table), derives from a normative priority criterion; and how needs theory (specifically Doyal and Gough's 
Theory of Human Need) matches the structure of thinking about human rights and human security, which prioritize criteria of human dignity and vital interests.

The table illustrates a number of other important themes too. First, we need a more refined and systematic vocabulary than just the single concept of public goods. We should consider not only the culmination outcomes of publicness, but also the comprehensive outcomes necessary to produce them (Sen, 2002). Thus, we need to distinguish between, for example: values that support education, economic inputs to schooling, real opportunities for schooling within a given social context, actual presence in school, actual involvement in learning, and actual achieved learning. Giving attention to all levels in the table shows the relevance of a range of levels and types of public good. Even if capabilities are deemed the true ends in policy deliberations, this should be accompanied by attention to the motivations, processes and arrangements concerning many required public goods and their prerequisites too.

Second, we noted that the language of public priority goods can be used too parochially, with certain groups being downgraded as supposed reflection of a particular society's local values. In contrast the languages of human security, human development and human rights are universal not nationally-specific, and add an essential framework for local prioritizations. They allow local variation in detailed content and emphases but not local exclusion of fundamentals. For example, basic physical and mental health is central in the Doyal-Gough theory of need, and brings implications such as in regard to reproductive health and to sanitation, as vital for general health and dignity. viii

Third, public spirit can be thought of as a special type of public good that is needed for the provision of most/many other public goods. It is hinted at in Doyal and Gough's preconditions level, and becomes explicit in work such as Nussbaum's. Many elements of culture, such as a public framework for respectful and systematic deliberation, are priority public goods. Personal capabilities rest in important degree on public goods provision; which in turn rests on appropriate institutional arrangements that themselves rely on, and sustain, compatible public sentiments.

\section{The Rawlsian, Senian and Nussbaumian dimensions of publicness}

Much of Amartya Sen's work on India has been about how to organize the provision of basic public goods. However the stress in his theoretical work, and in the Human Development Reports that this helped to foster, has been on how provision of concrete public goods should not be taken as the true standard of achievement. In contrast to what we named the Rawlsian level of public goods-basic/primary goods-Sen focuses on the degree of effective access to valued functionings. For both Sen and Rawls, a question arises regarding motivational adequacy: why would or do participants give support and/or concede duties regarding the specified concerns? So we look here at the essential complementary dimension, which we 
called the Nussbaumian level or dimension: the culture and attitudes-including of civility, tolerance, non-violence, mutual respect and solidarity-needed to sustain a life with dignity for all.

Rawls introduced in $A$ Theory of Justice the concept of 'publicity', meaning "a knowledge of the principles that others follow" (1971: 16). This idea of shared knowledge was expanded on in his Political Liberalism, in relation to 'justification' for a public conception of justice that comprises a commonly shared and justified point of view. In a liberal society individuals do not need to agree with each other's comprehensive doctrines nor do they have to hide their beliefs under a common point-of-view. Rather, they adjudicate disagreements by openly arguing in favour of their convictions in terms that others could potentially agree with. This 'reasoning together' is central to Rawls's vision of public reason, mutual respect and cooperation in 'a well-ordered society'.

In Justice as Fairness Rawls emphasises that his idea of public reason applies only to matters of "constitutional essentials and questions of basic justice" (2001: 91), excluding issues like 'tax legislation', 'environmental legislation' and 'laws regulating property' among others. He distinguishes between a 'constitutional stage' and a 'legislative stage'. Larmore (2003: 381) notes that "Political debate rightly shows a greater mix of voices in areas of society other than the circumscribed realm of public reason, and it would be wrong to suppose that Rawls's theory of public reason means to encompass the 'public sphere' in this broader sense". In contrast, Sen proclaims a much wider role of public reason, not restricted to specifying a constitution.

If we wish to apply Rawls's concepts of publicity and public reason in the domains of human development, we need a broader understanding of mutual respect, reasonableness, reciprocity, justification and shared principles, not restricted to a constitutional stage. We need a concept such as publicness that encompasses processes in which citizens can arrive at binding decisions and also includes 'background culture' elements. Rawls himself frequently used the concepts of 'reasonableness' and 'reciprocity' as ways to circumvent the limited scope of his concept of public reason. He never sufficiently establishes though why participants in his system would pay serious respect to public reasoning and, fundamentally, treat each other as of equal moral worth. He argues, "We develop a desire to apply and to act upon the principles of justice once we realize how social arrangements answering to them have promoted our good and that of those with whom we are affiliated." (1971: 474). But acceptance of such 'affiliation' involves more than just recognition of interdependence; for example, people depend on their physical environment and know this, but that does not mean they accept the environment as an agent that deserves moral recognition and has ethically binding rights. A feeling of affiliation with others requires further elements of psychological preparedness (Newman, 2015). 
In The Idea of Justice Sen argues (2009: viii) that "A sense of injustice could serve as a signal that moves us, but a signal does demand critical examination, and there has to be some scrutiny of the soundness of a conclusion based mainly on signals". Moral sentiments, such as frustration and ire, provide a starting point but need reasoned scrutiny, for us to understand and test with impartiality and objectivity the grounds for the indignation. For Sen, public reason involves judgment, in particular through impartial reasoning that can help people handle their vested interests and preconceptions. He acknowledges as did Rawls the plurality of relevant values and how some irreducible conflicts between different positions can remain, and considers how we can respond. "Judgements about justice have to take on board the task of accommodating different kinds of reasons and evaluative concerns" (2009: 395). He argues that such reasoning can make progress despite noncommensurability of values and the multiple types of reason.

Sen gives emphasis to characteristics of good public reasoning such as impartiality and objectivity, more than to defining 'reasonable persons'.ix His interpretation of Rawls's notion of fairness, as a demand for impartiality, frees him from examining the existence or not of reasonable behaviour as a precondition for public reason. He criticises Rawls though for not being 'realistic' (2009: 81), in assuming that once institutions are in place individuals would behave reasonably, and warns too that: "Demanding more from behaviour today than could be expected to be fulfilled would not be a good way of advancing the cause of justice" (2009: 81).

Sen seems more concerned with informational issues and how different arguments can survive objective reasoned scrutiny than with trying to change people's moral sentiments, at any rate directly. "To prevent catastrophes caused by human negligence or callous obduracy, we need critical scrutiny, not just goodwill towards others" (Sen 2009: 48). He emphasises good public reasoning, even when there is no change in individuals' emotions. His arguments for using social choice theory as a framework for public reasoning do not depend on criteria about reasonable values; instead he delves into the informational limitations that a complete theory of justice, such as Rawls's, inevitably encounters. Thus, Sen engages with Rawls's earlier concept of publicity as shared knowledge (necessary for shared communication and understanding) and his later characterization of justification in Political Liberalism; much more than with the psychological and moral principles that are needed to produce and give some stability to public reason itself. Yet if, as he argues, "justice is partly a relation in which ideas of obligation to each other are important" (2009: 129), we should address how values of reciprocity and of recognition of each other's equal moral worth are formed. In Sen's hands this becomes a cognitive challenge about open impartiality and objectivity. He notes that a person's objectives can go well beyond self-interest but he prefers to focus on the plurality of possible reasons without settling for any specific motivating moral sentiment. There is nothing irrational in being concerned with others, he shows, but 
he does not seem to insist that there is an obligation to be concerned, including for sake of one's own psychological health (Gasper 2007).

Sen prefers to focus on the issue of responsibility and cooperation, leaving open the possibility of plural justifications of reasonable behaviour (either based on self-interested mutual cooperation or on feelings of responsibility and duty towards others) rather than settling for a particular version. By using the concept of 'agency'-which "encompasses all the goals that a person has reasons to adopt" (2009: 287) - he builds a framework that includes a plurality of motivations (of which reasonableness can be one, but not 'the' one) rather than settling on one specific notion of reasonableness or reciprocity as the basis of individuals' sense of values. The adequacy of his approach depends on whether or not we actually need some shared human values for achieving kinds of public reasoning that are conducive to just arrangements.

Nussbaum disputes that the ideas of agreement and justifiability can sustain a notion of the good sufficient for a theory of justice. She criticises Rawls's contractarianism for having a very narrow moral psychology that excludes motivations such as compassion, sympathy or benevolence (2006: 108, 148, 158). She advocates a shared public conception of the person, ${ }^{\mathrm{x}}$ and proposes to replace Rawls's idea of mutual advantage by an idea of equal human dignity within a "richer and moralized account of the good" (2006: 163). ${ }^{\text {i }}$ Her argument is that people's notions of the good should (and do) include other people, and not for the reason that a person might feel better when doing charity or would gain some advantage from caring for others. Respecting each other's dignity is a question of our love of others. "It can only be out of our attachment to justice and our love of others, our sense that our lives are intertwined with theirs and that we share ends with them." (2006: 222).

\section{Nussbaum's Political Emotions ${ }^{\text {xii }}$}

All values require an emotional basis for them to be stable and to connect to action (Nussbaum 2013: 127). Securing a stable basis for commitments that concern other people is especially necessary. How for example, asks Nussbaum, could the project of the European Union acquire a sufficient motivational base amongst ordinary people (p.222)? Political Emotions asks how a liberal theory of justice can cohere; how can one, without imposing illiberal restrictions, ensure that individuals will pay attention to a common good? She sees a corresponding gap in Rawls' Theory of Justice, even though "Rawls...knows well that human beings do not automatically pursue the common good" (2013: 9).

She rejects as illiberal a family of responses that involve indoctrination plus enforcement to ensure solidarity or at least obedience to practices of solidarity; for example Rousseau's advocacy of a 'civil religion' that would, in his words, inculcate the "sentiments of sociability without which it is impossible to be a good citizen or a 
faithful subject" (cited on p.5). Implicitly she rejects the contemporary equivalents in East Asia. Indeed she rejects Rousseau's General Will doctrine, on grounds that it has insufficient respect for individuals (p.45). Further, it can accompany a type of overriding nationalism and conduce to lack of respect for other nations and individuals. We ask later whether Political Emotions' own nation-centred conception avoids nationalism's pitfalls.

She is more sympathetic towards Auguste Comte's and especially J.S. Mill's calls for a 'religion of humanity' to ensure a sufficient basis of altruism, and Rabindranath Tagore's similar call for a 'religion of man'. Comte's model for promotion of 'civic love' for fostering the common good, a sort of obligatory humanistic state religion in the mould of Catholicism but intended to replace it, leant too far in her view towards imposing feelings of obedience, hierarchy and homogeneity. She draws inspiration instead from Mozart, Mill and Tagore on how moral sentiments of general sympathy, equal respect, toleration and fellow-feeling, and deeper emotions such as compassion and altruism, can be promoted: including through arts, education, urban design, and style and content of leadership. Each of these can advance sympathetic awareness of other people. While some violations of core political values, such as racial discrimination, should be coercively prevented, the main focus of her proposals is within a liberal tradition, to non-coercively educate people and their emotions.

She does not agree that impartiality and objectivity in public reason suffice for appropriate behaviour. Reason and even respectxiii are not enough to connect people, unlike emotions. xiv "Rational deduction alone will not tell us whether women are full-fledged human beings" (2013: 261). Only through emotions, she argues, can individuals examine their lives and connect with each other, gaining a sense of a common fate and publicness stronger than implied by Rawls and Sen (2013: 345). Indeed, beyond what they suggested, human development needs a fuller set of ideas about what is good and bad. She holds that there is nothing illiberal about this provided that dissent is protected. Senian values of impartiality and objectivity must rest on empathy and sympathy with others; Rawlsian reasonableness requires specific psychological bases (Newman 2015). Nussbaum, like Newman, tries therefore to explain what shapes individuals' commitment to public reason. She looks specifically at the 'malleability of the moral sentiments' and how we can upgrade, within the limits of liberalism, individuals' emotional life towards others.

Political Emotions is dedicated to how decent societies should cultivate appropriate public emotions. Calls to respect the dignity of every human do not suffice to overcome inherited and newly created beliefs that some groups are disgusting (p.380). Nussbaum proposes that "all of the core emotions that sustain a decent society have their roots in, or are forms of, love-by which I mean intense [benevolent] attachments to things outside the control of our will" (2013: 15). For public emotions-attitudes towards other people whom one does not know personally or closely - to themselves be stable, and stable sustainers, they need to be 
part of a love of humanity in its finitude and particularities, that transcends any shame and disgust at being human, feelings which too often become projected onto others. Here Nussbaum sees her work as advancing beyond Comte and Mill, Rawls or Sen or Habermas, and even Tagore, for she theorizes "the link between overcoming disgust and broadening sympathy" (p.105). To understand limited sympathy and to counteract it requires existential investigation beyond mere recognition of the existence of a plurality of narrowly-concerned agents. We must give attention to negative emotions, including anger, shame and hatred. As discussed in her pivotal Chapter 7, these emotions derive from humans' long early years of self-absorbed conscious helplessness; also from, as remarked by Kant, our greater tendency compared to other species towards self-importance, hurtful comparisons with our fellows and "competitive self-love" (p.166); and from our in-group socialization which builds identity and in-group commitment partly through vilification of an out-group or groups. Ideally, gradually the loving attention of parent-figures builds a child's recognition, trust, and concern for others, and her confidence in her ability to reciprocate, and reduces her felt insecurities. However, "the dynamics in human life that made love necessary (helplessness, fear and anger at helplessness) are not [fully or once-for-all] removed by time and growth, but persist-and thus love is an ongoing necessity for the personality in adult interactions" (p.190).

While we traditionally invoke fraternité as necessary third term from the 1789 rallying cry, Nussbaum suggests this sort of masculine idiom contains a potential trap. ${ }^{x v}$ Her analysis of The Marriage of Figaro draws out the need and possibility for something more feminine, 'nicer', less oriented to competitive pride, status and domination. Her proposed solution inside nations, perhaps even outside them, centres on 'love'; by this she seems to mean empathy plus sympathy and generosity, 'love' in a somewhat Christian sense (cf. p.43). ${ }^{\text {vi }}$ Its attentive generous reciprocation, explored in Chapter 7, is not to be equated with 'being in love'.

Nussbaum stresses that the central importance of public emotions for solidarity does not imply that people should have completely the same values. First, a distinction is necessary between each individual's full set of ethical principles and the shared principles they endorse for the political sphere in order to avoid dictatorial regimes. Second, "Political emotions are the real emotions of real people; because people are heterogeneous, having different opinions, histories, and personalities, they can be expected to love, mourn, laugh, and strive for justice in specific and personal ways - particularly if their freedom of expression is protected and valued, as it is here" (2013: 382-3). Third, our minds are 'particularistic' and our emotions depend on the connections we have with people who belong to our 'circle of concern'. But the histories that partly define circles of concern are substantially shared within and partly specific to national societies: "What moves people is a function of their sense of their nation's history, traditions and current problems" (2013: 200), as she illustrates from the oratory of Lincoln and Martin Luther King. This last point implies great challenges. 
To extend our feelings of concern beyond those to whom we are directly connected-and to include within a 'we' some others whom we do not personally know-requires, she argues, the mediation of "symbols and poetry" (p.11). Art can help to convey both a tragic perspective that "gives insight into shared vulnerabilities", and a comic perspective that accepts the chances and peculiarities "of human existence with flexibility and mercy, rather than hatred" (2013: 21).xvii Vitally, all societies need formats-including the arts of tragedy and more-that channel grief "in ways that promote reciprocity and extended, rather than narrow compassion" (p.201), ways that lead us to have not only self-pity but sympathy for others too; and formats-including the comic arts-that restrain disgust, "lest it become an impediment to general concern" (p.201) and be projected onto hated out-groups, like blacks, Arabs or Untouchables.

Thus, Nussbaum examines the importance and substance of public emotions and proposes that they can be cultivated by societies in liberal ways. Publicness too can be built and refined as basis for the sustenance of public emotions. By doing this she extends the basis of justification beyond impartiality and reason, moving the discussion towards specific contexts and active cultural and communication strategies.

\section{An initial assessment of Political Emotions}

Nussbaum's treatment, within the frame of 'political liberalism', is oriented to look for institutional arrangements that allow coexistence of multiple ethical doctrines and yet fulfilment of the human rights of all people. She is more at home discussing art than the institutionalization of empathy, sympathy and solidarity in tax systems or public sanitation. She does discuss urban planning, though mainly with reference to public monuments and parks. Still, she is well aware that "a decent tax system, for example, could represent the insights of a duly balanced and appropriately impartial compassion" (2013: 20), and that "tax and welfare policies...embody sympathy, but in a way that is more stable and less prone to special pleading than is sympathy in [daily interpersonal] life" (2013: 135).

We do not look to a humanistic philosopher to go deep into the specifics of institutionalization, but can gain necessary insights and tools. Let us sketch an assessment then with attention more on building blocks of her analysis: the ideas about moral sentiments, and her strong commitments to liberalism and a nationstate framework. First, Nussbaum sometimes takes liberalism as a normative praise term, not a descriptor of actual societies: "A liberal society asks people to be ashamed of excessive greed and selfishness" (2013: 23); but which liberal society does that? Her left-liberalism (cf. Fawcett 2015) has to acknowledge that reallyexisting liberalism becomes illiberal in regard to weaker groups and persons, and needs to be bounded. 
Second, in regard to the moral sentiments, a comparison of Nussbaum's work with that of Adam Smith and earlier philosophers is needed, though that requires another paper. Suffice it to say that she shares many features seen in Smith and others: stresses on the plurality of moral sentiments, the importance of context, and the ongoing struggles to formulate and balance different emotions, as part of reasoning about living. (See also Nussbaum 1995, 2001.) The struggles never end, regardless of how much Mozart, Tagore and dance-drama one imbibes.

We look here instead at how Nussbaum's notions of moral sentiments relate to contemporary psychological research as reviewed in Jonathan Greene's Moral Tribes. Greene distinguishes two fundamental issues. The first concerns the bases for morality within a group: the issue of 'Me versus Us', as in The Tragedy of the Commons; members' selfishness versus concern for others. This is the problem that our moral brains evolved to solve. Greene writes that our brains contain responses to the group weakness that would be produced in relation to other groups if our group failed to cooperate internally. Various mechanisms encourage principled cooperation, such as cultures of group loyalty (Chapter 2).

The second issue, 'Us versus Them', concerns clashes of our group's interests and values with those of another group or groups. Our established solutions for the Me versus Us problem-including loyalty to our group, its declared symbols and mores-can exacerbate the second problem (Chapter 3). Greene speaks therefore of The Tragedy of Commonsense Morality. Besides mechanisms of biased perception and communication, seen in all disputes, that lead us to focus on our own grievances, here the group loyalties feed conflicts. We internalize sheer preference for our own 'tribe' and commitment to its declared distinctive values and the icons that supposedly embody them (particular places, persons, traditions, narratives); we embrace certain beliefs and stories about the past that become badges of 'tribe' membership and loyalty and so cannot be abandoned; and we acquire loyalties to particular doctrines about justice, which makes negotiated compromise harder for that would be to deviate from one's beliefs about justice.

Nussbaum illustrates this sort of trade-off from Finland, where the acceptance of high and progressive taxation reflects, she considers, the strong intra-group bonding possible in a small country (2013: 345). The relevant conducive factor is perhaps homogeneity more than smallness, for a large country like Japan displays similar intra-group bonding. Finland's homogeneity and internal bonding contribute to fear of in-migrants and asylum seekers; the same seems to apply for Japan.

Much of what Political Emotions describes matches Green's 'Commonsense Morality', notably various forms of quasi-religion concerning the nation, which can serve to exacerbate inter-group and inter-national conflict. Some of what she describes does not match that, and seeks to transcend such conflicts. So, thirdly, we need to review and assess her presumption and endorsement of a nation-state frame. 
Nussbaum adopts Mazzini's optimistic $19^{\text {th }}$ century claim that the nation is the necessary focus for transcending self-concern, and the unavoidable stepping-stone towards global concerns. xviii It is "the largest unit we know until now that is decently accountable to people's voices..." (p.17). Further, she frequently lauds patriotism, love of country, and adopts the theory that "when national love focuses on ideals of inclusion and human dignity, such love can easily lead on to a struggle for these things everywhere" (p.235). There is a Scandinavian grain of truth in this hypothesis, but unfortunately many counterexamples too: internally inclusive nations which remain resolutely self-obsessed. Further, a notion of the nation as that which brings a heritage to which all its members are indebted, which in fact has produced them, and which provides a horizon of opportunity to which they all can contribute, applies more validly to the world as a whole. (It applies also for cities and localities.)

The book's dominant categories are those of the age of nations, in which in many respects the world indeed remains. In other respects, as citizens of advanced globalized capitalism in the Anthropocene age, we are long past the nation as sufficient frame for our analyses and our moral imagination. Political Emotions functions mainly as an American text for an intended American audience, as seen throughout its final chapter. Even its closing paragraphs are exclusively nationfocused. It needs to be read together with Nussbaum's earlier cosmopolitan studies.

Nussbaum's analysis goes deeper than Greene's by exploring emotional sources and contents, not least the emotions of disgust. Our next section, on India, looks at the issue of disgust targeted at 'outsider' groups within a country; and the following section considers nationalism versus internationalism, and the languages of political emotion that are needed to build international cooperation, including to counter disgust targeted at other countries, a theme on which Political Emotions is surprisingly relatively silent.

\section{India's Challenge}

While Political Emotions includes much rich discussion of Indian themes and figures, there are sometimes uneasy links between its framework and these materials. "The focus of this project will be on the role of emotions in advancing a society that is already pretty good to fuller social justice" (p.136.) India though continues to display dismayingly low levels of publicness. The message from Comim's composite index mentioned earlier is corroborated in surveys of Indian human development such as by Drèze and Sen (2013) and the India Exclusion Reports (CES, 2014, 2016). The Exclusion Reports focus on the Rawlsian level of public goods and who gains access to them, as part of an agenda of holding the state accountable. Drèze and Sen focus on the levels of effective access to priority functionings and corresponding satisfiers, for example facilities and practices for basic sanitation. Half of the households in India still practiced open defecation in 2011 (Drèze and Sen, 2013: 63), six or seven times the proportion in Bangladesh. 
We saw that required for sustained provision of priority public goods, for effective access, and for activism that succeeds to hold the state accountable on behalf of everyone and not only mobilised privileged partisan groups, are public values of solidarity. Nussbaum refers frequently to "our tendency to feel disgust toward bodily fluids" (2013: 114), and of how this is counteracted or not. An equal or greater problem concerns our solid excreta, and this problem is definitive of Indian social organization and of challenges India continues to face. Her Chapter 7 describes how we may project onto groups of other people our disgust at excreta and mortality, by associating those groups inseparably with such products and with corpses, human and/or animal. In India this tendency was built into a social system. A "disgust-ridden way of life...is not very promising as a basis for a political community" (p.141); notably the "disgusted repudiation of mortality itself, and [of] the body as its seat" (p.160).

India presents a hard case for the approach advocated in Political Emotions. The book gives extended attention to the thoughts of Rabindranath Tagore, Mahatma Gandhi and Jawaharlal Nehru. It extols the norms of material modesty that they bequeathed to some of privileged India. Those norms have withered, and were never accompanied in most of the country by operational basic rights for all. Chapter 8 has a section on the Untouchables' (Dalits') great spokesman B.R. Ambedkar, and records the problems that Dalits continue to face rather than solutions via political liberalism and liberal arts. In higher education, Nussbaum thinks the legal infrastructure has been created, and attributes failures in integration to the social/emotional support structure of government [education] institutions' (p.371). Ambedkar (1949) had warned that "Without fraternity, equality and liberty will be no deeper than coats of paint."

The subject of sanitation in particular could need the enlightenment of both tragic and comic art. But neither seems to provide sufficient traction in the setting of India. Similarly, the question arises whether political liberalism, built in Europe and America, is enough for India. Will public sanitation in India, for example, only be achieved if adopted by a neo-Hindu modernization agenda and set of sentiments? Each country has its peculiar path.

Wuyts (1992) summarizes how richer groups in 19th century Europe's expanding cities, increasingly residentially secluded by income, paid private entrepreneurs who installed water and sanitation systems for their neighbourhoods. Eventually however these public goods were extended to low-income areas by legislation and State subsidy, given the richer groups' wish to eliminate epidemics that endangered and inconvenienced them too, and the growth of concern from increasingly organized medical and State bureaucracies and wider public opinion. In contrast in mid-20th century South Africa, richer groups responded to insanitary lowincome areas not by extending public provision to them but, from the 1930s onwards, by forced removal of their populations to remote townships. In Europe, the middle and upper classes evidently could imagine that misfortunes might happen to 
them too. In India, as in apartheid South Africa, not all of the elements of tragic art emphasized by Nussbaum seem actively present: that the audience should come to feel that the characters whom they watch suffer misfortunes that are major but which are largely not the characters' fault, that these misfortunes are avoidable and/or remediable, and that similar misfortunes could plausibly happen also to members of the audience. Attention and sympathy in India, let alone action, are not sufficiently triggered. The option of 'Looking Away' prevails (Mander 2015).

India, a continental-scale country of over a billion people stretching from amongst the richest in the world through to almost half of its poorest, is in some ways a microcosm for the world as a whole. What Indian elites allow to happen is comparable to what global elites allow to happen on the global scale. India has no single 'Us', except perhaps in the context of rivalry and conflict with a competitor nation. Its Dalit intellectuals reject as hypocritical the symbols of national unity provided by Indian elites. We come to the questions of how far the apparatus of national pride and commitment which Political Emotions gives such weight to suffices, whether nationalism is a dead-end (in all senses) in a shared world, and what are the possible alternatives or supplements.

\section{Global challenges}

Nussbaum's book proposes the elements of a national society founded in justice. She aims to complete Rawls's mid-20 $0^{\text {th }}$ century intellectual project and the projects of Rousseau, Comte et al. from earlier centuries. When Comte and Mill spoke of 'the religion of humanity' they meant a secular replacement for Christianity, in a world of nation-states. Like Mazzini, Mill presumed that nationalism's downsides were readily tameable, in a brotherhood of democratic peoples (Mazower 2013). In his declared long-term aims he was cosmopolitan, if not in his 35-year career as a senior British East India Company colonial administrator (Lal 1998).

Is this project, for well-ordered national societies, sufficient for the interwoven and seething globe of the 21st century, with its swelling 'public bads' and huge global public goods deficits? Nussbaum has elsewhere affiliated her perspective to the human rights tradition, but Political Emotions contains little or no discussion of that global agenda; nor are sister enterprises like the Earth Charter mentioned. While she frequently quotes Walt Whitman, especially his "Song of Myself"-in which "I will accept nothing which all cannot have their counterpart of on the same terms" (cited on p.296), she presumes that he proclaimed an ideal for America. She does not highlight his cosmopolitan declaration: "One thought ever at the fore - / That in the Divine Ship, the World, breasting Time and Space, / All peoples of the globe together sail, sail the same voyage, / Are bound to the same destination."

Nussbaum repeats classic arguments that particularist loyalties-here patriotism-are inevitable and also necessary in order to give our loyalties sufficient strength to motivate cooperative action. Following Aristotle, she claims 
cosmopolitanism offers merely 'watery motivation' (p. 219). Following Mazzini, she says ordinary people need a local focus (p.209); yet her main cases, the USA and India, are continental-scale countries. She admits that Martin Luther King himself intended the phrase "all God's children" to imply what it says, a global scale of concern (p.239) but holds that few Americans accept that; likewise for Gandhi (p.242). She doesn't directly address the question whether a local loyalty needs to be exclusive; does 'love of the nation' (p.313) exclude love of many nations or love for them all? ${ }^{x i x}$ But she warns that any eschewing of the heritage and symbols of patriotism would leave cosmopolitan forces hopelessly politically marginalized (p.256). So, in the world as it has evolved, with its longstanding locally accepted stories of each local group's great contributions and/or unjustified sufferings, we could now be stuck with nationalism.

She frequently repeats Mazzini's mid-19th century argument that nationalism forms a necessary and serviceable emotional bridge beyond the self and the locality, leading eventually to commitment to the world as a whole, a hypothesis much battered by the $20^{\text {th }}$ century. Political Emotions' longest chapter, entitled "Compassion's Enemies: Fear, Envy, Shame", does not include Nationalism in that list. Yet nationalism is imbricated with each of those enemies and is an additional underminer of compassion. It condones different standards for one's own cause; its prideful love suppresses many truths about oneself and others, and promotes contemptuous distortions about the others. Nussbaum does recognize this, and elsewhere notes how J.G. Herder (1744-1803) rejected the crude patriotism and masculinist blood lust that fed into wars (p.47ff.); but she holds that those problems are avoidable (p.212). 'Compassion's Enemies' stresses that love tends to be particularistic, limited by or to person or group-specific loyalties (p.318); its subsequent discussion calls only for concern within the nation. The chapter concludes with the assertion that "we cannot uproot particularism without uprooting love itself" (p.376). An earlier chapter is devoted to 'Teaching Patriotism'.

Some elements of the book take us further than this, through the words of two figures who in the 1940 s clearly stepped beyond the frame of the $17^{\text {th }}$ to $19^{\text {th }}$ century project which Rawls later continued, and moved to a more global frame: F.D. Roosevelt and Jawaharlal Nehru. Nussbaum cites their words but does not seem here to follow through their full spirit. Nehru's great independence speech, 'A tryst with destiny', expounded commitment to not only the new India, and the tasks that awaited it, but to all humanity, in a now indivisibly interknit world:

These dreams are for India, but they are also for the world, for all the nations and peoples are too closely knit together today for any one of them to imagine that it can live apart. Peace has been said to be indivisible, so is freedom, so is prosperity now, and so also is disaster in this one world that can no longer be split into isolated fragments. (Nehru, 1947; cited by Nussbaum 2013: 247).

Roosevelt, responding to the obligations of the leading power in this interknit world, adopted a firmly global language and scope. The paralysis of his legs, which 
had struck him in the prime of life, had empowered his compassion. He took the American language of freedoms and extended it, to include positive freedoms-real capacities to achieve valued outcomes-and to apply it worldwide. Nussbaum notes how Roosevelt insisted, against his advisers, that his 1941 "Four Freedoms" State of the Union speech should extend his vision of basic human freedoms to apply to the whole globe. He paired the rethinking of freedom with a rethinking of fear and security. Security now meant the secure achievement of four basic freedoms: freedom of speech, freedom of worship, freedom from want, and freedom from fear, not the last only. The final two in particular were interdependent. Conflict and fear can directly undermine prosperity, and undermine concern for others. Fear frequently weakens also the ability to learn about and understand others, thus indirectly undermining societal cooperation. Nussbaum provides a local example: "When fear dominated [University of Chicago] thinking, impeding inclusive sympathy, steps were taken that made things less safe as well as less hospitable" (p.338). This perspective, at a global scale, became foundational in the United Nations system founded in 1945 , incorporated in its themes of human rights and human security. These offer a framework for mutual respectful awareness, inclusive sympathy, and prudence and compassion in action (Jolly et al., 2009).

Human security thinking emphasises the logic of (global) public goods-the logics of the public sanitation system and global environmental change-that there can be no security in one neighbourhood alone. It can also help to motivate cooperation to supply and maintain public goods, by its promotion of perception of human co-membership in a global socio-ecological system. Public goods provision cannot be reduced solely to calculations of self-interest, otherwise free-riding by selfishly calculating participants can destroy the system. As we saw, stable and sufficient provision of public goods rests also on public spiritedness: pride in and commitment to the collectivity. Authors like Joseph Stiglitz and Nicholas Stern, who helped to build a reductionist economics of public goods, now fall back on the spirit of universal human rights and "the vision, communication and organisation of Gandhi and Mandela" (Stern 2010: 183), when seeking to imbue motivation to act against climate change (see Gasper 2013).

The public and political emotions needed for the $21^{\text {st }}$ century should support global citizenship, not just the national projects of previous centuries. Greene warns us that many solutions to Problem I, the tension between public duty and selfinterest within a group, exacerbate Problem II, the conflicts of interest between different groups. Solving problem I by nationalism (solving Me v. Us by emphasizing Us v. Them) condemns us to not solve problem II. Harder still is Problem III, the issue of regulating and managing entry to the group. Rawls avoided discussing migration and refugees, including by suggesting that out-migration only arises if a country's State has culpably failed. ${ }^{\mathrm{xx}}$ The clash between East European immigration and the expectations generated by English nationalism seems to have destabilized the arrangements for dealing with problem II within and via the European Union. At 
play too are emotions of fear and disgust in relation to (potential) refugees and migrants. The metaphor of knitting, of identities and emotions, becomes central for the economically and environmentally interknit world of hyper-modernity. It is an old image, which Nussbaum notes in Aristophanes' Lysistrata set in the context of wartime $5^{\text {th }}$ century BC Athens. The metaphor referred to linking Athens' different classes and groups, including immigrants and foreign denizens, to create a strong society. Nationalist forms of knitting ease Problem I but by stoking Problems II and III. We need, as Nussbaum suggests while commenting on Chicago's Millennium Park, cultural, organizational and architectural forms that promote "a love of diversity in one's fellow citizens, and a sense that diversity is a source of pleasure, not of anxiety" (2013: 300).

\section{Conclusion and lines for further work}

Much work tries to illuminate empathy, sympathy and their absence (see e.g. Krznaric 2015) but much less connects this to public goods. This essay reflected on public goods' provision or neglect and the connection to issues of publicness. It recognized that public attitudes involve emotions and perceptions, both crude and complex, not just arbitrary tastes or given selfish calculations. The essay can generate many types of further work, not least a fuller investigation and delineation of concepts. We conclude with an underlining of main themes and by noting some of the lines for further attention.

First, public goods are essential components in human development. Public priority goods at a series of levels can be identified by a logic of derivation from normative priority principles. An underlying premise of the paper has been that what we consider highly developed countries are countries with higher levels of publicness, in the sense of both public goods provision and the associated public spirit. We can list arguments of various natures in support of such a link; but to explore and test it requires research.

Second, public-spiritedness is essential for public goods provision, operation and maintenance. Shrinkage of the notion of 'public' to that in neoclassical economics matches a domination of the political community by wealth (Gasper 2002), as we see at the world scale too.

Third, the operative normative priorities in a society depend on the quality of effective concern shown by more powerful groups and majorities for their weaker fellows. Drèze and Sen, Mander and others document the enormous continuing neglect of basic public goods for the poorer half of the population in, as leading example, India. Mander starts to address the perceptual and emotional, as well as political and institutional, forces related to this absence of public concern and public spirit. Wider work on public sentiments should be brought into fuller conversation with work in and on India, notably on specifics of the struggles and debates around provision of particular public goods. 
Fourth, Nussbaum's Political Emotions goes much further in theorizing public spirit than do the thoughts of Mander, Rawls or Sen. It addresses gaps in the work of Rawls and Sen regarding motivations and how actions against (and for) injustice arise. She presents and uses a complex theory of emotions, to help think about the formation of public attitudes. Further work that could be useful includes to compare her arguments with those of Adam Smith on moral sentiments, and with the tradition of thinking about 'the common good'. We need to also connect more concretely, in research and practice, such work on emotions to work on campaigns for public goods; we may learn, for example, from the movement for the 'right to the city', including for migrants.

Fifth, Nussbaum's intellectual project in Political Emotions is within the nation, following the framework in most Western political philosophy. She assumes here that the nation is the inevitable, relevant, workable framework for human life. But the defining challenges for the $21^{\text {st }}$ century-in relation to environmental change, migration forced or induced by economic, environmental and demographic changes, and so on-involve issues of global public goods not only national public goods. Since, in Whitman's words, all peoples of the globe sail in the same boat, a relevant model for public emotions will examine also Nussbaum's earlier work on Stoics and cosmopolitanism, and connect to work on political cultures for human rights and human security. Roosevelt and Nehru, amongst others, foresaw the insufficiency of the nationally bounded imagination. The 'solution' of problems of national order via reliance on nationalism is likely to condemn us to fail on problems of global order.

$* *$

\section{References}

Ambedkar, B.R., 1949. Speech to Indian Constituent Assembly, November 25, 1949.

Anand, P.B., F. Comim, S. Fennell, J. Weiss (eds; forthcoming). Oxford Handbook of BRICS and Emerging Economies. Oxford University Press.

CES, 2014. India Exclusion Report, 2013-2014. New Delhi: Centre for Equity Studies, www.indianet.nl/pdf/IndiaExclusionReport2013-2014.pdf

CES, 2016. India Exclusion Report, 2015. New Delhi: Centre for Equity Studies

CHS, 2003. Human Security Now, New York: UN Secretary-General's Commission on Human Security Comim, F., 2015. "Development and Publicness: Rawls, Sen and Nussbaum." Paper presented at the HDCA conference, September 2015, Georgetown University, Washington DC.

Crocker, D., 2008. Ethics of Global Development. New York: Cambridge University Press.

De Swaan, A., 1988. In Care of the State: Health Care, Education and Welfare in Europe and the USA in the Modern Era. Cambridge, UK: Polity.

Douglas, M., and Ney, S., 1998. Missing Persons: a Critique of the Social Sciences. Berkeley, CA: University of California Press.

Doyal, L., and Gough, I., 1991. A Theory of Human Need. Basingstoke: Macmillan.

Drèze, J., \& Sen., A., 1989. Hunger and Public Action. Oxford: Clarendon Press.

----, 2013. An Uncertain Glory: India and its Contradictions. London: Allen Lane. 
Evans, P., 2002. "Collective Capabilities, Culture, and Amartya Sen's Development as Freedom". Studies in Comparative International Development, 37(2), 54-60.

Fawcett, E., 2015. Liberalism - The Life of an Idea. Princeton University Press. Expanded edition. Frederickson, H.G., 1996. Principles for South African public administration in the transformation decades: an American perspective. Pp. 298-323 in Burger, A.P.J., Theron, F., van Rooyen, A. (eds.), Challenges in Change, Bellville: Stellenbosch University.

Gasper, D., 2002. "Fashion, Learning and Values in Public Management," Africa Development, 27(3), $17-47$.

Gasper, D., 2005: "Securing Humanity - Situating 'Human Security' as Concept and Discourse." J. of Human Development, 6(2), 221-245.

Gasper, D., 2006a. "Working in Development Ethics - a tribute to Denis Goulet." Ethics and Economics / La revue Éthique et Économique, 4(2), 1-24.

Gasper, D., 2006b. "Cosmopolitan Presumptions? On Martha Nussbaum and her Commentators." Development and Change, 37(6), 1227-1246.

Gasper, D., 2006c (ed.) "Cosmopolitanisms and the Frontiers of Justice." Development and Change, 37(6), 1227-1334.

Gasper, D., 2007. "Adding Links, Adding People, Adding Structures - Using Sen's Frameworks." Feminist Economics, 13(1), 67-85.

Gasper, D., 2013. "Climate Change and the Language of Human Security." Ethics, Policy and Environment, 16(1), 56-78.

Goldewijk, B.K., and Fortman, B. de G., 1999. Where Needs Meet Rights. Geneva: WCC Publications.

Goulet, D., 1971. The Cruel Choice. New York: Atheneum

Gray, J., 1993. Beyond the New Right - Markets, government and the common environment. London: Routledge.

Greene, J., 2015. Moral Tribes - Emotion, Reason, and the Gap Between Us and Them. London: Atlantic Books

Jolly, R., Emmerij, L., Weiss, T.G., 2009. UN Ideas That Changed the World. Bloomington, IN: Indiana University Press.

Krznaric, R., 2015. Empathy. London: Rider Books/Random House.

Lal, V., 1998. "John Stuart Mill and India, a review-article." New Quest, no. 54 (January-February 1998): 54-64.

Larmore, C., 2003. "Public Reason". In: Freeman, S. (ed) The Cambridge Companion to Rawls. Cambridge: Cambridge University Press, 368-393

Mander, H., 2015, Looking Away: Inequality, Prejudice and Indifference in New India. Delhi: Speaking Tiger.

Mazower, M., 2013. Governing the World: The History of an Idea. London: Penguin.

Nehru, J., 1947. Speech On the Granting of Indian Independence, August 14, 1947. https://legacy.fordham.edu/halsall/mod/1947nehru1.html

Newman, O., 2015. Liberalism in Practice: the psychology and pedagogy of public reason. Cambridge, MA: MIT Press.

Nussbaum, Martha, 1995."Emotions and Women's Capabilities", in Nussbaum \& J. Glover (eds.), Women, Culture and Development, Oxford: Clarendon Press; 360-395.

Nussbaum, Martha, 2001. Upheavals of Thought. Cambridge University Press.

Nussbaum, Martha, 2006. Frontiers of Justice. Harvard University Press.

Nussbaum, M. 2013. Political Emotions - Why Love Matters For Justice. Harvard University Press

Pattanaik, P., 2014. "Introduction". In: Maskin, E. and Sen, A. (2014) The Arrow Impossibility

Theorem. New York: Columbia University Press.

Peter, F., and Schmid, H.B. (eds.), 2007. Rationality and Commitment. Oxford University Press.

Rawls, J., 1971. A Theory of Justice. Harvard University Press.

Rawls, J., 1993. Political Liberalism. Columbia University Press. 
Rawls, J., 1999. The Law of Peoples. Harvard University Press.

Rawls, J., 2001. Justice as Fairness. Harvard University Press.

Raz, J., 1986. The Morality of Freedom. Oxford: Clarendon Press.

Sen, A., 2002. Rationality and Freedom. Harvard University Press.

Sen, A., 2009. The Idea of Justice. London: Allen Lane.

Sennett, R., 2012. Together: the rituals, pleasures and politics of cooperation. London: Penguin.

Sennett, R., 1977. The Fall of Public Man. New York: Knopf.

Smith, Adam, 1759. Theory of Moral Sentiments. Ed. K. Haakonssen, Cambridge Univ. Press, 2002.

Stern, Nicholas, 2010. A Blueprint For A Safer Planet, London: Vintage Books.

Wuyts, M., 1992. "Deprivation and Public Need" in M. Mackintosh, T. Hewitt, M. Wuyts. Development Policy and Public Action, eds. Oxford University Press, 13-37.

\footnotetext{
' Compared to its treatment of public reasoning and dialogue, Sen's The Idea of Justice contains much less on commitment. Similarly, Crocker (2008) extensively lists public reason in its index but not public goods, public sentiments or emotions.

ii See e.g. papers in Peter and Schmid (2007) on Sen's concept of 'commitment'. Commitment can be to abstract entities too, notably the nation; those more abstract commitments can be in tension with commitment to concrete others.

iii Comim (2015) discusses what indicators we can use for trends in publicness, such as in levels of childhood protection, other legal protections, urban planning, public spending, homicides, etc.

iv The composite index employed, for the Rawlsian level, public expenditure on health as \% of GDP; for the Senian level, a blend of the under-5 mortality rate and expected years of schooling; and for the Nussbaumian level of how people deal with each other, the homicide rate. Despite India's relatively low homicide rate, it comes bottom on the resulting composite index ratings: at 0.3 on a 0-1 scale, whereas China, Russia and Brazil all appear in a different universe of publicness, around 0.7; only South Africa, at around 0.4, is close.

${ }^{v}$ Some of this section uses ideas from Gasper (2002).

vi Rivalrousness: my consumption of a good means that you cannot consume it. Excludability: exclusion from access to a good can be implemented at an affordable cost.

vii For Drèze and Sen (1989) public action is action for public benefit, which can be done by various agents, including private agents too.

viii See, e.g., CES (2014) on the frequent absence of separate girls' toilets in schools in India, and its implications.

ix Sen (2009: 43) holds that "all of us are capable of being reasonable through being open-minded about welcoming information and through reflecting on arguments coming from different quarters, along with undertaking interactive deliberations and debates on how the underlying issues should be seen".

' The point is what counts as someone's good. For Nussbaum: "The person leaves the state of nature not because it is more mutually advantageous to make a deal with others, but because she cannot imagine living well without shared ends and a shared life. Living with and toward others, with both benevolence and justice, is part of the shared public conception of the person that all affirm for political purposes" (2006: 158).

${ }^{x i}$ In her words (2006: 295), "For the capabilities approach, at any rate, equality is important at the very base of the theory; for it is not just human dignity that must be respected, it is equal human dignity."

xii Nussbaum's terminology oscillates between 'political emotions', the title of the book, and 'public emotions', the title of its second half. The former category is perhaps broader, encompassing also for example concerns for heritage and legacy; but the book does not discuss the distinction. Ch.1 rapidly adopts 'public emotions' (pp. 2,3) and leaves the meaning of 'political' somewhat hazy: "all those institutions that influence people's life chances pervasively and over the entire course of their lives (John Rawls's notion of 'the basic structure" (p.16). xiii She argues that (2013: 380), "Respect on its own is cold and inert, insufficient to overcome the bad tendencies that lead human beings to tyrannize over one another."

xiv "If people talk without tapping into their emotions, they often don't really understand the depth of the problem, or communicate their full thinking to others." (Nussbaum 2013: 289). "...the public culture cannot be tepid and passionless, if good principles and institutions are to survive: it must have enough episodes of inclusive love, enough poetry and music, enough access to a spirit of affection and play, that people's attitudes to one another and the nation they inhabit are not mere dead routine" (2013: 320).

${ }^{x v}$ She is herself often content though with the term 'fraternity' for fellow-feeling and solidarity (2013:37).
} 
xvi For example: St. Paul in 1 Corinthians, 13:4-7 and 13:13.

xvii She discusses US Government use of photographs of victims of the Great Depression to illustrate the tragic perspective.

xviii P.121 claims her Frontiers of Justice provided a full defence of this presumption. See commentaries in Gasper (2006b, 2006c).

xix Do any national anthems honour all humanity? Possibly only the European Union anthem, a marginal case.

${ }^{\mathrm{xx}}$ The index of Moral Tribes too has no mention of the basic issue of migration/immigration. 